\title{
The Introduction of Calculation at The Preparatory Center in Islamic Kindergarten Nibras Padang
}

\author{
Wulansari Vitaloka \\ Early childhood education, STIT YPI Kerinci, Indonesia \\ vitalokawulansari@yahoo.co.id
}

\begin{abstract}
Keywords:

Numeracy,

Preparation Center,

Kindergarten.

The problem in this research is the center approach as a learning model is still not used in KINDERGARTEN. Because teachers have not understood the center approach and the introduction of counting in children is not optimal, it is difficult for teachers to determine the right method. The purpose of this research is to describe the methods used by teachers in the identification of calculation at the preparatory center at the Islamic kindergarten Nibras Padang. The research methods used in this study are descriptive with a qualitative approach. The informant in this study was the teacher at the center of preparation as well as the principal. The results of this research can be concluded that the method used in the introduction of calculation of the preparation center in TK Nibras Islam is at the reception of the teacher's child using the question and answer method, on the footing before playing the teacher using methods of play, methods of giving assignments and methods of demonstration, on footing during the main teacher using methods of play, question and answer methods, demonstration methods, experimental methods and methods of dramatization, on the footing after playing the teacher using methods of play, question and answer methods, and methods of storytelling.
\end{abstract}

Article History:

Received: 28-06-2018

Revised : 19-08-2018

Accepted: 28-08-2018

Online : 30-08-2018

\author{
This is an open access article under the CC-BY-SA license

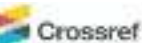 \\ https://doi.org/10.31764/ijeca.v1i2.2133
}

\section{A. INTRODUCTION}

According to Anderson in Masitoh "Education for kindergarten children needs to provide a variety of activities that can develop various aspects of development that include cognitive, language, social, physical and motor" (Masitoh, 2008). And in the Law on national education system No. 20 of 2003 article 14, it is explained that "early childhood education is a coaching effort aimed at children from birth to the age of six years through the introduction of the provision to help physical and spiritual growth and development so that children have readiness to enter further education".

Kindergarten education is a very large investment for families and nationalities. Children are the successor generation of the nation, as educators in kindergarten are expected to develop the potential for children. Wachs in Sujiono says that "cognitive development can be improved when people around the child are loving, verbally responsive and provide an organically and predictable environment with possibilities for variation of experience" (Sujiono. Dkk., 2010). The experience will be in being able by the child when the child plays as described by Tedjasaputra that: "Playing closely related to cognitive development, playing is essential for the 
development of personal and emotional social. Through play, children experience a variety of emotional experiences; Loved Sad Passionate Disappointed Proud Angry and so on. Through playing children understand the link between him and his social environment, learn to get along and understand the rules or Ordinances of association. (Tedjasaputra, 2007)

A learning Program that can develop the children's potential in kindergarten is integrated in the field of development intact, which includes the field of habituation and development of basic skills. One of the areas of basic capability development is cognitive ability, related to mathematics, which needs to be developed in early childhood mathematics, one of which is arithmetic skills. Counting in kindergarten is necessary to develop basic knowledge of mathematics so that children are ready to follow the learning of mathematics further.

Seeing the importance of children learning to count, then counting in the kindergarten is done in the process of learning by the way while playing. A synergistic learning approach with a learning strategy while playing is a learning approach to BCCT (Beyond Centers and Circle Time) or a central approach to circles, Depdiknas explained the center approach is "the approach of education organizing early childhood that focuses on children in the process of learning centers Disentra play and when his learning process is centered in the center and when the children in the circle using 4 types of footing to support the development of children, i.e. (1) a main environmental foothold; (2) step before play; (3) footing during play; (4) the footing " (Kholifah et al., 2018). In fact kindergarten in general does not use the center approach in learning, only a few kindergarten that there is using the center approach one of the children's Islamic park Nibras Padang.

Based on the results of observations in the Islamic kindergarten Nibras Padang in group B at the center of preparation, there are children who have difficulty and are not interested in counting where the child is busy with himself and do not do counting activities, this is in because difficult for teachers to determine the right method in the introduction of arithmetic on each footing experience, teachers lacking in the method of arithmetic recognition, the method that the teacher uses is less functioning optimally.

The focus of problems on this research is on the method of counting learning that is used by teachers in introducing counting on group B at the center of preparation. This research was conducted to describe the method of counting learning at the preparatory center in the Islamic kindergarten Nibras Padang.

With the achievement of this research is expected to provide benefits for the parties such as: for the students can improve the development of children's counting skills, for kindergarten teachers, especially the Islamic kindergarten Nibras as input materials in helping kindergarten teachers to teach children counting, for schools to improve the quality of education in general and improve the learning process in particular so that children can achieve optimal learning outcomes and for further researchers, as preliminary information for further researchers to conduct further research.

\section{B. METHODS}

This type of research is descriptive research with a qualitative approach. Through this method, researchers will obtain data and information that gives an overview of the things that will be researched as per the research. As described by the Bungin (Bungin, 2011) that "qualitative descriptive research is to describe, summarize the various conditions, situations, or various social reality phenomena that exist in the society that become the object of research, and try to attract the reality itself to the surface as a feature, character, trait, model, sign, or image of a particular condition, situation, or phenomenon." So in this research researchers will collect various information to get the correct picture and what is about the introduction of counting in the Islamic kindergarten Nibras Padang. 
Meanwhile, to get the picture of Moleong (Lexy J. Moloeng, 2017) stating "to enter the work in the field, researchers need to understand the background of research first". Then the researcher first understands the background of research that will be researchers do which the research is done in the Islamic kindergarten Nibras Padang West Sumatra, precisely on Jln. Perak No. 5 A Kec. West Padang, behind the graduate of IAIN Imam Bonjol Padang. The study was conducted in the even semester of the 2012-2013 school year which took \pm 2 months from January to February 2012.

Moleong stated that "Informant is a person who is used to provide information about the situation and background conditions of research" (Lexy J. Moloeng, 2017). So he should have a lot of experience about the research background. The informant in this research is a person who is directly involved with the researched object, which is the teacher who teaches at the preparatory center and has a big influence on the research object namely the principal of the kindergarten of Islamic children in Nibras Padang. In this research the instruments used are observation formats, interview formats and documentation.

The data analysis technique used in this research is qualitative through several stages of data analysis as described by Miles and Hubermen in Sugiyono namely "Data Reduction, data Display (data presentation), Conclusion Drawing" (Sugiyono, 2017). The researcher's step is to record the observations that researchers have gained from documentation, interviews and observations, classify the data that has been obtained from the results of the documentation, interviews and observations, analyzing the data that has been obtained from the results of documentation, interviews, and observations, giving interpensi to data obtained from the research time by providing qualitative explanation, and concluded the data has been analyzed.

The way used in determining the data in this research is triangulation. As Moleong explained (Lexy J. Moloeng, 2017) "Triangulation is a data validity inspection technique that utilizes something else, beyond that data for checking purposes or as a comparison to that data". The triangulation technique in this study is examination through other sources. It is accomplished by way of: comparing data on observations (observations), interviews, documentation as well as Field records.

\section{RESULT AND DISCUSSION}

Based on the analysis of the data conducted by researchers discussed the method of calculation of counting on group B in the center of preparation conducted at TK Islam Nibras Padang, there are several methods used are the following:

\section{Play Method}

Play is a child's activity because at the same time, the child learns through their games so that the child has a pleasant experience from the play they are doing and this experience will be useful when they are grown, more importantly the child can enjoy the childhood park. Landhers in Montolalu stated that the rate of cognitive development at the age of 4 was $50 \%$, 4 to 8 years as much as 30\% and the remaining 20\% reached at the age of 9 to 19 years (Musfiroh, 2014). This shows that the knowledge of children at an early age to develop intelligence has a tremendous contribution to the lives of the next child. Given the many benefits of play for children, the children need to be given an inverse, encouragement, and support in the form of planned activities, appropriate methods, activities that are beneficial and enjoyable for children. 
Based on the above opinion, it can be concluded that by playing the child can enjoy the childhood park, playing at the age of kindergarten is very useful for the life of the next child. Here teacher roles are indispensable in the development efforts of potential children. Teachers should create a pleasant learning atmosphere that is done while playing the approach that can be used namely the center approach, the center approach is the approach of early childhood education training which focuses on children in the learning process centered around the center and when the children in the circle using 4 types of footing to support the development of children as explained by the Ministry: (1) The main environmental (2) step before play; (3) footing during play; (4) The footing after play.

The learning environment is made friendly to children so they feel familiar, if the learning environment is not familiar with them, then learning will be considered phobias and develop into laziness. Children of kindergarten age have unique characters, one of which is they love to play. Therefore, one of the challenges of teachers in teaching them is how to control them in order to keep learning focused while still wanting to keep playing. One of the things that can be done is to be a friend and teacher for them to play while learning. With this method of playing children not only sit still, but they are encouraged to be active. As the teacher's mother did introduce counting on the center of preparation by playing. Where teachers always observe and guide and become children's friends in play.

The method of play and center approach used is expected that the child will not feel when he is learning so that make learning activities become more flexible and not stiff.

\section{Giving Assignments Method}

The method of awarding assignments is a task that is deliberately given to a child kindergarten that must be implemented properly. The task was given to kindergarten children to give them the opportunity to complete the task based on the instruction directly from the teacher who has been prepared so that the child can live in real life and implement it from the beginning until complete. The task given to the child can be given individually or the group Moeslichatoen (Moeslichatoen R., 2004).

Based on the research the child has conducted activities that have been prepared with the teacher's instructions. Where teacher's mother gave instructions on how to play the game tool that has been set up. At the center approach of the given task method is used on the step before main as explained by Depdiknas one of the teacher's activities in the step before main is "introduce all the places and game tools that have been prepared" (Dewi et al., 2017). The verbal method of assignment gives children the opportunity to train their auditory perception, indirectly enhancing the language skills of the child in addition to the assignment method of coaching the child to focus on the activities it is doing, and the child motivated to complete the activities they are doing.

In this case, it can be concluded that the method of assigning a task is an activity performed by the child with instructions and guidance from the teacher used on the footing before playing. Assigning assignments to children can provide a direct learning experience to the child, where the child does the real process of counting from the activities they do with the object with so the children can learn the learning of counting. Through this assignment method the child can also develop his own learning activities, as in calculating Roncean there are 5 cylinders, 7 cubes, 4 round then child count the Ronceannya.

\section{Demontration Method}

Sujiono states that "the method of demonstration is how to demonstrate or demonstrate something or process from an event or event" (Sujiono. Dkk., 2010). It can be said that 
demonstration is an activity that shows, works, and explains. So in the demonstration the teacher showed and explained the ways of doing things, through the demonstration of the child will be able to know the steps of implementation. The teacher uses this method of demonstration on the step before the play and the footing after the play.

At the time before the main child will be able to see directly what the teacher has done so that the child easily understand an activity that is somewhat difficult for the child, with the method of demonstration is very helpful child in doing its activities. At the time of footing during the main method of demonstration can be used to attract children's attention so that the child is attracted to the counting play. For a child see how something events take place more interesting and stimulating attention than the child listens to the explanation of the teacher alone.

This method of demonstration is often combined with other methods, for example, in the method of assigning teachers have difficulty in explaining with words on how to use a game tool counting teachers using a method of demonstration in explaining to the child. So that the child is more easily imitating what teachers do. The demonstration method used by teachers will be able to attract the child's attention because the child sees the learning steps in real so that the child absorbs the teacher's information.

\section{Question and Answer Method/Converse}

Hildebrand in Moeslichatoen states "chatting means communicating with each other in verbal thoughts and feelings" (Moeslichatoen R., 2004). Conversing has an important meaning for the development of children's kindergarten because conversation can improve communication skills with others, improve skills in conducting activities together. Also improve the skill of expressing feelings, as well as expressing ideas or opinions verbally.

The method of conversation can develop aspects of development that the children have one of the same cognitive development, as described by Moeslichatoen that "the method of conversation is the ability to menalar, solve problems, know the physical environment, know the social environment, ability Menggolong-golongkan, crafting skills based on certain criteria, counting, know the symbols, know people and know the time. (Moeslichatoen R., 2004)

In conversing each child speaks of what is known, possessed and experienced to the teacher. Teachers and children are talking about the number of toys that have been compiled, how many people are present and absent etc. Conversing training the child's ability to listen to and understand what the teacher is talking about, clarity of understanding of what is being heard allows the child to respond to the order, answer, follow the sequence of events done, add information and so on so that the child can declare ideas, feelings and needs to the teacher. So many benefits of question and answer method so that teachers use this method in the introduction of counting at the center of preparation on each footing main environment.

\section{Saying Poetry Method}

Sujiono states "The method of saying a poem is a way of conveying something through an interesting poem, which the teacher has made for something, so that the child can be understood". (Sujiono. Dkk., 2010)

The method to pronounce poetry in developing children counting at the center of preparation is never used by teachers. This is because the learning of counting is more effective if the child immediately do counting activities, if the teacher uses the method of saying the child's poetry does not get the concept of counting itself and the child just hear it without any real evidence that the child sees. 
In this case the researcher concluded if the teacher does not use the method of saying the poem in group B because it makes the child is not focused and noisy and busy with himself because the child B group more engrossing learning for him when the child plays with the game tools he used.

\section{Experimental Methods}

The experimental method is a form of activity involving children, children playing with objects, materials, both individually and in groups where the method of experimental/experimental children can solve the problem or find the answers of the activities it works.

Sujiono stated that "the experimental/experimental method is a way for children to conduct a variety of experiments that children can do according to their age, teachers as facilitators, tools for various experiments have been prepared by the teacher" (Sujiono. Dkk., 2010). Through this experimental/experimental method the child can find something based on his experience, it will be very meaningful to the child because the child himself who has done the activity and find the answers to the activities he does and the child get real evidence of the activities he does.

The experimental/experimental method used by teachers is very effective in developing child counting skills because the child is directly working on the activities that the teacher has prepared so that this is meaningful for the child. This experimental/experimental method is carried out on a foothold during play, the child plays while experimenting with the game tools.

\section{Storytelling Method}

Children love the story, if the story is interesting, it will invite the child's attention. The kids love the fantastic, strange things, which makes her imagination "danced". The child can ask the teacher to read the same story many times if the child likes the teacher's read story. Storytelling in children can also develop the potential for child counting by hearing and then relive it again for the purpose of training children's skills in conversing to convey ideas in oral form. The story will be easily understood by the child when attributed to the children's life of kindergarten thus they will easily capture what the teacher is told.

Moeslichatoen stated that "the storytelling method is one of the children's kindergarten learning experiences by bringing the story to the children orally" (Moeslichatoen R., 2004). The story the teacher must draw by conveying the story of a reasonable motion and varied intonation so that the desired goal can be achieved.

The method of story used by teachers in developing children's counting skills is done by reading the artwork or pictures of the child on the footing after the play, the child is very pleased if his work is read by the teacher to his friends, they are proud of his work and the child learns to appreciate his friend's work by watching the teacher tell about his friends ' work. This is interesting for children because the work is read by the teacher close to the child's environment.

\section{Karyawisata Method}

Tourism has an important meaning for the development of children because it can arouse the child's interest in something and broaden the information obtained by the child. According to Sujiono "The method of tourism is a visit directly to objects around the child according to the purpose to be achieved" (Sujiono. Dkk., 2010).

Based on the above opinion, we can know that the method of tourism is one of the methods of learning that gives the child the opportunity to observe or observation, and obtain information directly, through the activities of the work of children will gain learning 
experience directly using the entire five senses, so that the things obtained from the field can be more effective and in turn will be longer settle in the child's memory

Based on the results of the research teachers held a tour called the theme visit at the Islamic kindergarten Nibras Padang. This method of travel or theme visits further leads the child to add to their insight into the theme, where it is not taught specifically to count on the visit of this theme. Actually, this method of tourism can also be done by the teacher in introducing calculation at the center of preparation by leaving the time the child plays Disentra preparation and invites the child to walk around the school location and calculate the objects that exist around the child. The child can be invited to count certain items of different children, it will be very interesting for the child.

\section{Dramatization Methods}

Sujiono states "The method of dramatization is how to understand something through the roles of the character or objects around the child, so that the child can understand something while imagining it" (Sujiono. Dkk., 2010). Children play characters according to their choices based on interest. Like the son of his roncees and considers his results as a snake and the imaginary child calculates his length by counting the number of beads in his roncenya. Master method using dramatization method in introducing calculation in group B at the center of preparation when the child has started with the role he and the teacher responds to the child back with the role of the teacher, this can make the child feel unignored and the development of the ability of the children can also develop. This dramatization method is done when the child is playing or footing during play.

\section{CONCLUSION AND SUGGESTIONS}

Based on the research that researchers do, it can be known that the calculation method used in the preparation center is when the welcome of the teacher's child using the question and answer method, on the footing before playing the teacher using methods of play, methods of giving assignments and methods of demonstration, on footing during the main teacher using methods of play, question and answer methods, demonstration methods, experimental methods and methods of dramatization and on the footing after the main teacher using the method of play, question and answer methods, and methods of storytelling.

Based on the results of the research that has been exposed above, can be given some advice, in hopes that the child counting ability can develop and teachers should be more flexible using methods of learning to introduce counting on children and the school should better improve the quality of the school by enhancing the creativity and ability of teachers in developing learning Itung with the right method and for the next researcher in the hope to examine and convey the idea of the learning methods used in developing children's counting skills and researching other areas related to the development of children's counting ability.

\section{ACKNOWLEDGEMENT}

By saying Alhamdulillah, I offer this happiness For the authority and unreplaceable figureThe father of Bustanuddin, S. Pd and Female figure full of patience and affection Nilti Erfia's mother, S. PdI. My Dearest Sisters Junef Adhani Bustanil, SST and Dimas Aziza Bustanil Who always inspires writers To always strive to achieve the best. 


\section{REFERENCES}

Bungin, B. (2011). Penelitian Kualitatif: Komunikasi, Ekonomi, Kebijakan Publik, Dan Ilmu Sosial Lainnya. In Kencana. https://doi.org/10.1002/jcc.21776

Dewi, F. Y., Rini, R., \& Sofia, A. (2017). Pendekatan Beyond Centers and Circle Time (BCCT). Jurnal Pendidikan Anak, 3(1). http://jurnal.fkip.unila.ac.id/index.php/PAUD/article/view/14096/10248

Kholifah, R. N., Hendarwati, E., \& Setiawan, A. (2018). Pengaruh Strategi Pembelajaran Beyond Centers And Circletime (Bcct) Terhadap Kreatifitas Anak Usia Dini Kelompok Usia 3-4 Tahun Di Pos Paud Nusa Indah Surabaya. Pedagogi: Jurnal Anak Usia Dini Dan Pendidikan Anak Usia Dini, 4(1), 75. https://doi.org/10.30651/pedagogi.v4i1.3608

Lexy J. Moloeng. (2017). Metodologi Penelitian Kualitatif (Edisi Revisi). PT Remaja Rosdakarya.

Masitoh. (2008). Strategi Pembelajaran TK (1st ed.). Universitas Terbuka.

Moeslichatoen R. (2004). Metode pengajaran di Taman Kanak-Kanak. Rineka Cipta.

Musfirah, T. (2014). Bermain dan Permainan Anak. Universitas Terbuka. http://repository.ut.ac.id/id/eprint/4699

Sugiyono. (2017). Sugiyono, Metode Penelitian. Penelitian, 34-45. https://doi.org/10.1021/ol7029646

Sujiono. Dkk. (2010). Metode Pengembangan Kognitif. Jakarta : Universitas Terbuka.

Tedjasaputra, M. S. (2007). Bermain; Mainan dan Permainan untuk Pendidikan Anak Usia Dini. Gramedia. 